\title{
EFFECT OF DEPOLARIZING AGENTS ON CHOLINE ACETYLTRANSFERASE AND ACETYLCHOLINESTERASE ACTIVITIES IN PRIMARY CELL CULTURES OF SPINAL CORD ${ }^{1}$
}

\author{
ISAO ISHIDA² AND TAKEO DEGUCHI \\ Department of Medical Chemistry, Tokyo Metropolitan Institute for Neurosciences, 2-6 Musashidai, Fuchu-city, Tokyo 183 \\ Japan
}

Received December 3, 1982; Revised April 12, 1983; Accepted April 14, 1983

\begin{abstract}
In cultured neurons dissociated from the spinal cord of fetal mouse, high concentrations of $\mathrm{KCl}$ $(47 \mathrm{mM})$ increased choline acetyltransferase (CAT) activity up to 5.5 -fold but suppressed acetylcholinesterase (AChE) activity to less than half the level of control cells. Veratridine $(3 \mu \mathbf{M})$ also increased CAT activity 1.6-fold and suppressed AChE activity to the same level as that induced by high $\mathrm{KCl}$. The increase of CAT activity by the depolarizing agents was blocked by $\mathrm{Ca}^{2+}$ antagonists (verapamil and high $\mathrm{Mg}^{2+}$ ) and in a low $\mathrm{Ca}^{2+}$ medium, whereas the suppression of $\mathrm{AChE}$ activity by high $\mathrm{KCl}$ was restored by the same procedures. The synthesis of radiolabeled acetylcholine from $\left[{ }^{14} \mathrm{C}\right]$ choline was also enhanced 4 -fold by incubating cells in high $\mathrm{KCl}$ medium. Although the uptake of $\mathrm{L}-\left[{ }^{3} \mathrm{H}\right]$ leucine and $\left[{ }^{14} \mathrm{C}\right]$ choline into the cells was slightly enhanced by high $\mathrm{KCl}$ medium, neither the total amount of protein nor the incorporation of $\mathrm{L}-\left[{ }^{3} \mathrm{H}\right]$ leucine into protein was increased by high $\mathrm{KCl}$ medium. These observations indicate that depolarization increased CAT activity in a specific manner, that the activities of CAT and $\mathrm{AChE}$ changed inversely under several conditions, and that the effect of depolarization presumably was mediated by the entry of $\mathrm{Ca}^{2+}$ into neuronal cells. The findings raise the possibility that trans-synaptic input could play a crucial role in the development of the activity of cholinergic neurons in spinal cord.
\end{abstract}

Preganglionic input has been shown to be essential for the normal development of autonomic neurons (Black, 1978). Black and his co-workers (Black et al., 1971; Black and Geen, 1974) demonstrated that, in the superior cervical ganglion of neonatal mouse, the developmental increase in postsynaptic tyrosine hydroxylase activity was markedly retarded by transection of the preganglionic trunk or by treatment with ganglionic blockers. Since one immediate consequence of synaptic transmission is membrane depolarization, the trans-synaptic regulation of neuronal properties presumably is mediated through a depolarization of postsynaptic neurons. Such a mechanism has been demonstrated in cultured neuronal tissues. Patterson and Chun (1974) showed that cultured neurons dissociated from rat superior cervical

\footnotetext{
${ }^{1}$ This research was supported in part by Grant-in-Aid for the Encouragement of a Young Scientist (Grant 57771553), for Scientific Research (Grant 57480151), and for Special Project Research on "Metabolic Responses and their Disorders" from the Ministry of Education, Science and Culture of Japan.

${ }^{2}$ To whom correspondence should be addressed.
}

ganglion differentiated into either adrenergic or cholinergic neurons, depending on culture conditions. The neurons treated with depolarizing agents or stimulated directly by electric current tended to display an adrenergic character, which was presumably induced by the entry of $\mathrm{Ca}^{2+}$ into the cells by depolarization (Walicke et al., 1977). Nishi and Berg (1981) also reported that a high $\mathrm{KCl}$ concentration enhanced choline acetyltransferase (CAT) activity, protein synthesis, and other activities in neurons cultured from chick ciliary ganglion. Depolarization by high concentrations of $\mathrm{KCl}$ increased the number of surviving neurons and stimulated the differentiation of cerebellar neurons (Lasher and Zagon, 1972), dorsal root ganglion neurons (Scott, 1977; Chalazonitis and Fischbach, 1980), sympathetic neurons (Philipson and Sandler, 1975), and ciliary ganglion in cultures (Bennett and White, 1979; Nishi and Berg, 1981). Thus, presynaptic impulses would exert a crucial control over the activity and properties of postsynaptic neurons.

We have been investigating the factors that affect the development of the enzymes involved in the synthesis and degradation of neurotransmitters in cell cultures 
from the spinal cord of fetal mouse. In this communication, we report that depolarizing agents change the activities of CAT and acetylcholinesterase (AChE), which were reversed by $\mathrm{Ca}^{2+}$ antagonists.

\section{Materials and Methods}

Chemicals and media. $\mathrm{I}-\left[4,5-{ }^{3} \mathrm{H}\right] \mathrm{I}$ eucine $(58 \mathrm{Ci} /$ mmol), $\left[\right.$ methyl $\left.{ }^{14} \mathrm{C}\right]$ choline $(59 \mathrm{mCi} / \mathrm{mmol}),\left[1-{ }^{14} \mathrm{C}\right]$ acetylcholine $(9.86 \mathrm{mCi} / \mathrm{mmol}), \mathrm{L}-\left[1{ }^{14} \mathrm{C}\right]$ glutamic acid $(50$ $\mathrm{mCi} / \mathrm{mmol})$, and $\left[1-{ }^{14} \mathrm{C}\right]$ acetylcoenzyme $\mathrm{A}(4.05 \mathrm{mCi} /$ $\mathrm{mmol}$ ) were purchased from The Radiochemical Centre, Amersham, U. K. N-Hydroxyethyl-4-(1-naphthylvinyl)pyridium bromide (NVP) was obtained from Calbiochem, La Jolla, CA; 5 -fluorodeoxyuridine (FUdR) was from Sigma Chemical Co., St. Louis, MO; and uridine was from Nakarai, Kyoto, Japan. Verapamil was a gift from Eizai, Tokyo, Japan. Culture medium consisted of Dulbecco's modified Eagle's medium (DMEM) supplemented with $0.45 \%$ glucose, $10 \mathrm{units} / \mathrm{ml}$ of penicillin, 10 $\mu \mathrm{g} / \mathrm{ml}$ of streptomycin, $5 \%$ fetal bovine serum (M. A. Bioproducts, Walkersville, MD), and $10 \%$ heat-inactivated horse serum (Toyo, Tokyo, Japan). A high $\mathrm{KCl}$ medium ( $55 \mathrm{mM}$ ) was prepared from its constituents by reducing $\mathrm{NaCl}$ from $109.5 \mathrm{~mm}$ in the normal medium to $59.9 \mathrm{~mm}$ in the high $\mathrm{KCl}$ medium. The osmolarity of the medium was adjusted to 290 milliosmoles by use of an osmometer (Fiske). The high $\mathrm{KCl}$ medium was supplemented with $5 \%$ fetal bovine serum and $10 \%$ horse serum to a final concentration of $47 \mathrm{mM} \mathrm{KCl}$. Low $\mathrm{Ca}^{2+}$ media were also prepared from their constituents as above.

Cell cultures. Dissociation and culture of spinal cord cells were performed as described (Giller et al., 1977; Ishida and Deguchi, 1983). Briefly, spinal cords were removed aseptically from $d d y$ fetal mouse of 13 or 14 days' gestation. Spinal cords were dissected into small pieces and dissociated by incubating with $0.1 \%$ collagenase (type I, Sigma) in balanced salt solution (BSS)HEPES solution $(137 \mathrm{mM} \mathrm{NaCl}, 5 \mathrm{mM} \mathrm{KCl}, 0.7 \mathrm{mM}$ $\mathrm{Na}_{2} \mathrm{HPO}_{4}, 25 \mathrm{mM}$ HEPES, $10 \mathrm{~mm}$ glucose, $0.36 \mathrm{mM}$ $\mathrm{CaCl}_{2}, 100 \mathrm{units} / \mathrm{ml}$ of penicillin, $100 \mu \mathrm{g} / \mathrm{ml}$ of streptomycin) at $37^{\circ} \mathrm{C}$ with constant agitation. The dispersed cells were suspended in culture medium and inoculated into collagen-coated 24 multi-well plates (Nunc) at a concentration of $3.75 \times 10^{5}$ cells/well. Cells were treated with $20 \mu \mathrm{g} / \mathrm{ml}$ of FUdR and $50 \mu \mathrm{g} / \mathrm{ml}$ of uridine from day 3 to day 5 of culture as described (Schrier and Shapiro, 1974). On day 5, the cells were washed with normal medium and cultured in either normal medium or high $\mathrm{KCl}$ medium containing the agents indicated. The media were changed every other day.

Enzyme assay. CAT activity was measured by the method of Fonnum (1975) as described previously (Ishida and Deguchi, 1983). The cells cultured in multi-well were rinsed with $0.5 \mathrm{ml}$ of $\mathrm{BSS}^{-\mathrm{CaCl}_{2}}$ solution $(137 \mathrm{mM} \mathrm{NaCl}$, $5.9 \mathrm{~mm}$ sucrose, $5.4 \mathrm{mM} \mathrm{KCl}, 0.17 \mathrm{~mm} \mathrm{Na} \mathrm{HPO}_{4}, 0.22$ $\mathrm{mm}$ glucose, $0.14 \mathrm{mM} \mathrm{CaCl}_{2}$ ) three times and solubilized with $10 \mu \mathrm{l}$ of $1 \mathrm{M} \mathrm{NaCl}$ containing $2.5 \%$ Triton X-100. To the well, $90 \mu \mathrm{l}$ of reaction mixture were added to a final concentration of $50 \mathrm{~mm}$ potassium phosphate $(\mathrm{pH}$ 6.8), $0.2 \mathrm{M} \mathrm{NaCl}, 8 \mathrm{~mm}$ choline chloride, $1 \mathrm{~mm}$ FDTA, $0.5 \%$ Triton $\mathrm{X}-100$, and $60 \mu \mathrm{M}\left[1-{ }^{14} \mathrm{C}\right]$ acetylcoenzyme A.
The culture plates were sealed with vinyl tape. After the reaction was carried out at $37^{\circ} \mathrm{C}$ for $60 \mathrm{~min}$, the radiolabeled acetylcholine $(\mathrm{ACh})$ produced was extracted and measured as described (Fonnum, 1975). The amount of the reaction product increased almost linearly for $60 \mathrm{~min}$ and was proportional to the amount of enzyme preparation employed. The validity of this assay method was examined by comparing the above method with another procedure (Giller et al., 1977), in which cultured cells were scraped, sonicated, and assayed in a test tube. CAT activity was the same with both methods. Nonspecific acetyltransferase activity was determined in the presence of $1 \mathrm{~mm}$ NVP (Cavallito et al., 1970).

For the assay of $\mathrm{AChE}$ activity, reaction mixture containing $50 \mathrm{~mm}$ potassium phosphate ( $\mathrm{pH} 6.8), 0.2 \mathrm{M}$ $\mathrm{NaCl}, 0.5 \%$ Triton X-100, $1 \mathrm{mM}$ EDTA, and $0.305 \mathrm{~mm}$ $\left[1-{ }^{14} \mathrm{C}\right] \mathrm{ACh}$ was added to the solubilized cells as described above. After $30 \mathrm{~min}$ of incubation at $37^{\circ} \mathrm{C}$, the radiolabeled choline produced was separated from $\mathrm{ACh}$ by use of a Dowex $50 \times 8$ column $(0.4 \times 4 \mathrm{~cm})$, and the radioactivity was measured as described by Wilson et al. (1972).

L-Glutamic acid decarboxylase (GAD) activity was also measured by the method of Wilson et al. (1972). In brief, cells were scraped from a well with $50 \mu \mathrm{l}$ of $50 \mathrm{~mm}$ potassium phosphate ( $\mathrm{pH}$ 6.8) containing 1 mM EDTA, $0.5 \%$ Triton X-100, $0.5 \mathrm{~mm}$ pyridoxal phosphate, and 1 $\mathrm{mM} 2$-mercaptoethanol, and were transferred into a test tube. The reaction was started by adding $50 \mu \mathrm{l}$ of the reaction mixture containing $1 \mathrm{mM} 2$-mercaptoethanol, $0.5 \%$ Triton X-100, $0.5 \mathrm{~mm}$ pyridoxal phosphate, $0.5 \mathrm{mM}$ L-glutamic acid potassium salt, $1 \mathrm{~mm}$ EDTA, $50 \mathrm{~mm}$ potassium phosphate (pH 6.8), and $0.05 \mathrm{mM} \mathrm{L}-\left[1{ }^{14} \mathrm{C}\right]$ glutamic acid $(50 \mathrm{mCi} / \mathrm{mmol})$. The reaction was carried out at $37^{\circ} \mathrm{C}$ for $60 \mathrm{~min}$ and was terminated by the addition of $0.3 \%$ acetic acid in methanol. The radioactive $\mathrm{CO}_{2}$ evolved was trapped and counted as described (Wilson et al., 1972).

Measurement of choline uptake and ACh synthesis. For the assay of choline uptake, cultured cells were incubated in $0.3 \mathrm{ml}$ of DMEM containing $5.6 \mu \mathrm{M}\left[\right.$ methyl $\left({ }^{14} \mathrm{C}\right]$ choline $(59 \mathrm{mCi} / \mathrm{mmol})$ for $1 \mathrm{hr}$ at $37^{\circ} \mathrm{C}$. The cells were rinsed with $0.5 \mathrm{ml}$ of $\mathrm{BSS}-\mathrm{CaCl}_{2}$ solution three times and dissolved in $0.5 \mathrm{ml}$ of $2 \%$ sodium dodecyl sulfate (SDS), and the radioactivity was measured by a scintillation counter.

For the measurement of ACh synthesis, cultured cells were incubated in $0.2 \mathrm{ml}$ of DMEM containing $42 \mu \mathrm{M}$ [methyl ${ }^{14} \mathrm{C}$ ]choline $(59 \mathrm{mCi} / \mathrm{mmol})$ for $4 \mathrm{hr}$ at $37^{\circ} \mathrm{C}$. The cells were rinsed with $0.5 \mathrm{ml}$ of $\mathrm{BSS}-\mathrm{CaCl}_{2}$ solution and extracted with $20 \mu \mathrm{l}$ of $0.47 \mathrm{mM}$ formic acid and $1.4 \mathrm{M}$ acetic acid ( $\mathrm{pH} 1.9)$. The extract $(10 \mu \mathrm{l})$ was placed on Whatman $3 \mathrm{MM}$ paper and the radioactive ACh produced was determined by high voltage paper electrophoresis as described (Hildebrand et al., 1971).

Incorporation of $\mathrm{L}-\left[^{3} \mathrm{H}\right]$ leucine into protein. Cultured cells were incubated in $0.3 \mathrm{ml}$ of DMEM containing 57 nM L- $\left[4,5-{ }^{3} \mathrm{H}\right]$ leucine $(58 \mathrm{Ci} / \mathrm{mmol})$ at $37^{\circ} \mathrm{C}$ for $1 \mathrm{hr}$. After incubation, the cells were washed with BSS-CaCl${ }_{2}$ solution three times, and trichloroacetic acid (TCA)soluble materials were extracted with $0.5 \mathrm{ml}$ of $5 \% \mathrm{TCA}$ 
twice. TCA-insoluble materials were washed with $70 \%$ ethanol twice and $100 \%$ ethanol sequentially, and dissolved in $0.5 \mathrm{ml}$ of $2 \%$ SDS.

Noncollagen protein was measured by the method of Bonting and Jones (1957).

\section{Results}

CAT activity in the primary cell cultures from the spinal cord of fetal mouse gradually increased 3- to 4fold during 6 to 8 days of culture (Fig. 1). The addition of high $\mathrm{KCl}(47 \mathrm{mM})$ markedly stimulated the development of CAT activity. There was a 2 -fold elevation of the activity after 2 days of culture. After 8 days of culture, the specific enzyme activity per milligram of protein and the total activity per well were elevated 5.5-fold and 5.2fold (total activity per well was not shown), respectively, in high $\mathrm{KCl}$ medium compared to control cells (Fig. 1). Figure 2 shows the concentration dependency of the increase in CAT activity on $\mathrm{KCl}$ in medium. There was a significant elevation at $21 \mathrm{~mm}$ and a maximum response at $47 \mathrm{mM} \mathrm{KCl}$. $\mathrm{KCl}$ higher than $47 \mathrm{mM}$ attenuated CAT elevation, probably due to a toxic effect on the cells. The CAT activity elevated by high $\mathrm{KCl}$ was completely inhibited by a specific CAT inhibitor, NVP (1.0 mM), whereas the basal activity was inhibited only $50 \%$ by the inhibitor (Table I). The observation indicates that high $\mathrm{KCl}$ increased CAT activity, whereas some of the basal activity was due to nonspecific acetyltransferase. In contrast to CAT activity, GAD and AChE activities decreased to $73 \%$ and $46 \%$ of control cells, respectively, by incubation with high $\mathrm{KCl}$ medium (Table I).

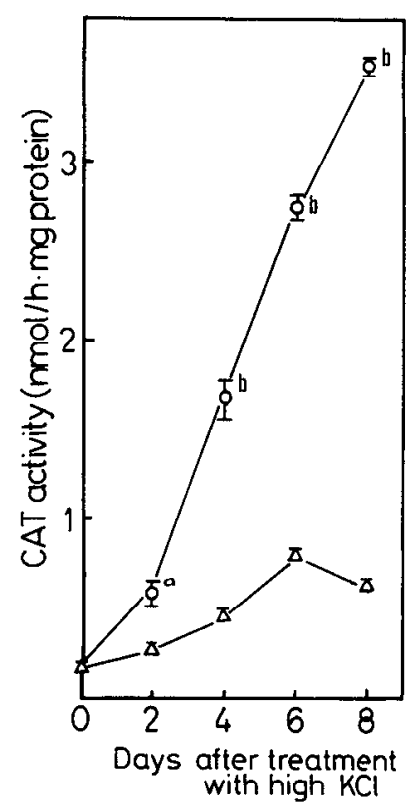

Figure 1. Time course of the responses of CAT activity to a high $\mathrm{KCl}$ concentration in cell cultures of spinal cord. The cells dissociated from spinal cord of fetal mouse were cultured from day 5 to day 13 in normal medium $(\triangle)$ or in a high $\mathrm{KCl}(47$ $\mathrm{mM})$ medium $(\mathrm{O})$. The cells were harvested at various time intervals as indicated, and CAT activity was measured. Points and bars show the mean and SEM of the values of four replicate cultures. $a, p<0.01 ; b, p<0.001$ compared to the cultures in normal medium in each time point.

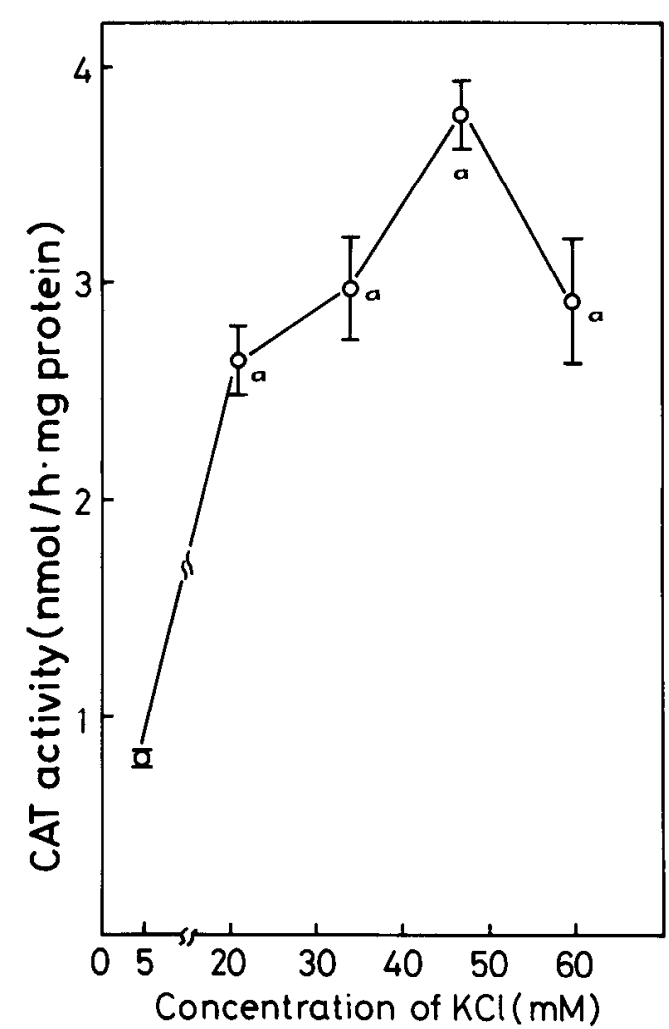

Figure 2. Dependence of the appearance of CAT activity on $\mathrm{KCl}$ concentrations of culture medium. Cells were grown for 7 days in the medium with the $\mathrm{KCl}$ concentration indicated, and CAT activity was assayed. Normal medium contained $4.5 \mathrm{mM}$ $\mathrm{KCl}$. The points and bars represent the mean and SEM of the values of four replicate cultures. $a, p<0.001$ compared with control cells.

To study whether the stimulatory effect on CAT activity was due to a depolarization-dependent $\mathrm{Ca}^{2+}$ influx into cells, spinal cord cells were cultured in a low $\mathrm{Ca}^{2+}$ medium or in the presence of verapamil that inhibited $\mathrm{Ca}^{2+}$ influx. The addition of verapamil into the medium did not significantly decrease the basal activity up to 25 $\mu \mathrm{M}$. The increase of CAT activity (per milligram of protein) by high $\mathrm{KCl}$ medium was inhibited by verapamil, decreasing to the basal level at $20 \mu \mathrm{M}$ (Fig. $3 A$ ). Total CAT activity per well also was decreased by verapamil to the same extent (data not shown). In low $\mathrm{Ca}^{2+}$ medium ( 0.05 to $0.5 \mathrm{~mm}$ ), the basal CAT activity gradually decreased to one-third of the activity of cells cultured in normal medium (Fig. $3 B$ ). CAT activity, elevated by high $\mathrm{KCl}$, was reduced more evidently in low $\mathrm{Ca}^{2+}$ medium, decreasing to the basal enzyme activity at 0.05 to $0.1 \mathrm{mM}$ extracellular $\mathrm{Ca}^{2+}$ (Fig. $3 B$ ). Veratridine $(3 \mu \mathrm{M})$, which depolarized neural cell membrane, also stimulated CAT activity 1.6-fold during 6 days of culture, which was again blocked in low $\mathrm{Ca}^{2+}$ medium and by the addition of verapamil (Fig. 4). A high concentration of $\mathrm{Mg}^{2+}$ that blocked $\mathrm{Ca}^{2+}$ influx into cells decreased the basal activity to half and prevented the increase of CAT activity by high $\mathrm{KCl}$ and veratridine. The stimulation of CAT activity by veratridine was blocked by $5 \mu \mathrm{M}$ tetrodotoxin, a sodium channel blocker (data not shown).

In contrast to CAT activity, AChE activity was de- 
TABLE I

Effect of a high concentration of $K C l$ on $C A T, G A D$, and $A C h E$ activities in cell cultures of spinal cord

Spinal cord cells were cultured either in normal medium or in a high $\mathrm{KCl}(47 \mathrm{mM})$ medium from day 5 to day 10 , when enzyme activities were assayed. The results are expressed as mean \pm SEM of quadruplicate cultures.

\begin{tabular}{|c|c|c|c|c|}
\hline & \multicolumn{2}{|c|}{$\begin{array}{c}\text { CAT Activity } \\
\text { (nmol/hr } \cdot \text { mg protein) }\end{array}$} & \multirow{2}{*}{$\begin{array}{c}\text { GAD Activity } \\
\text { (nmol } \mathrm{CO}_{2} \\
\text { evolved } / \mathrm{hr} \cdot \mathrm{mg} \\
\text { protein) }\end{array}$} & \multirow{2}{*}{$\begin{array}{c}\text { AChE Activity } \\
\text { (nmol/30 min } \cdot \mathrm{mg} \\
\text { protein) }\end{array}$} \\
\hline & $-\mathrm{NVP}$ & $+\mathrm{NVP}(1 \mathrm{~mm})$ & & \\
\hline Normal medium & $0.56 \pm 0.06$ & $0.26 \pm 0.03$ & $0.284 \pm 0.020$ & $17.07 \pm 3.21$ \\
\hline High $\mathrm{KCl}$ medium & $1.95 \pm 0.27^{a}$ & $0.24 \pm 0.05$ & $0.209 \pm 0.016^{b}$ & $7.85 \pm 1.47^{a}$ \\
\hline Ratio (High $\mathrm{KCl} /$ normal) & 3.48 & 0.92 & 0.73 & 0.46 \\
\hline
\end{tabular}

${ }^{a}$ Statistically significant difference in value compared to control cells, $p<0.01$.

${ }^{b}$ Statistically significant difference in value compared to control cells, $p<0.02$.
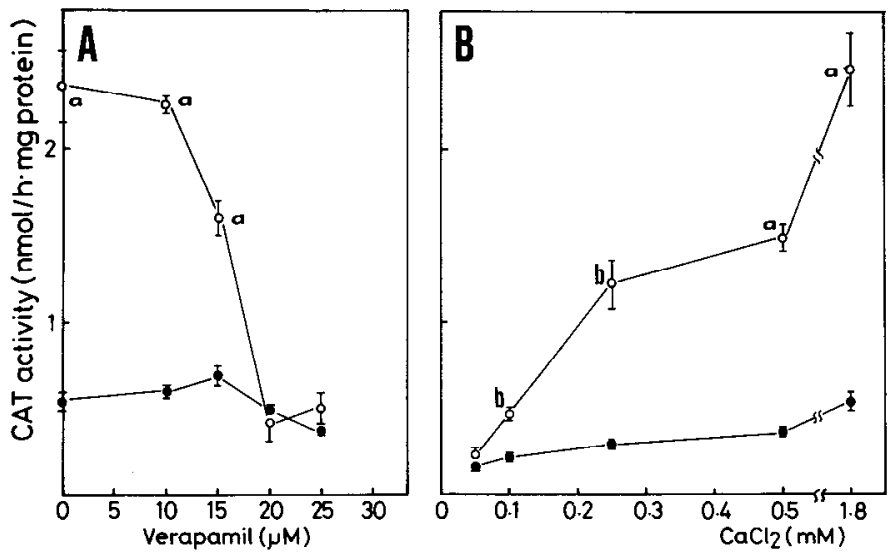

Figure 3. Effect of verapamil or a low $\mathrm{Ca}^{2+}$ medium on the increase of CAT activity by a high concentration of $\mathrm{KCl} . A$, Verapamil $(0$ to $25 \mu \mathrm{M})$ was added to the cells cultured in normal medium (-) or the cells cultured in a high $\mathrm{KCl}(47 \mathrm{mM})$ medium (O) from day 5 to day 11 of culture. $B$, Cells were cultured in the normal medium (O) or in the high $\mathrm{KCl}$ medium (O) containing $\mathrm{CaCl}_{2}$ as indicated from day 5 to day 11 , when CAT activity was assayed. Points and bars represent the mean and SEM of the values of four replicate cultures. $a, p<0.001$; $b, p<0.01$ when compared with the cells cultured in normal medium.

creased to $49 \%$ by high $\mathrm{KCl}$ medium and $42 \%$ by $3 \mu \mathrm{M}$ veratridine, but was restored to the control level by the addition of $20 \mu \mathrm{M}$ verapamil (Fig. 5). Verapamil slightly decreased the basal AChE activity. The decrease of AChE activity by a high concentration of $\mathrm{KCl}$ or veratridine was also restored by reducing the extracellular $\mathrm{Ca}^{2+}$ concentrations. In low $\mathrm{Ca}^{2+}$ medium, AChE activity in control cells was elevated 2.1 -fold. Thus AChE activity changed in the direction opposite to that of CAT activity under the conditions examined. These observations are very indicative that $\mathrm{Ca}^{2+}$ entry is essential for the increase of CAT activity and for the decrease of AChE activity induced by depolarization.

To study whether high $\mathrm{KCl}$ stimulates the synthesis of protein in a nonspecific manner, the incorporation of $\left[{ }^{3} \mathrm{H}\right]$ leucine into acid-soluble and acid-insoluble fractions was measured. A high concentration of $\mathrm{KCl}$ slightly (1.36-fold) stimulated the uptake of $\left[{ }^{3} \mathrm{H}\right]$ leucine into cells, but did not enhance the incorporation of $\left[{ }^{3} \mathrm{H}\right]$ leucine into the acid-insoluble fraction, protein (Table II). There was no difference in the amount of protein in the cells cultured in high $\mathrm{KCl}$ medium and control cells,

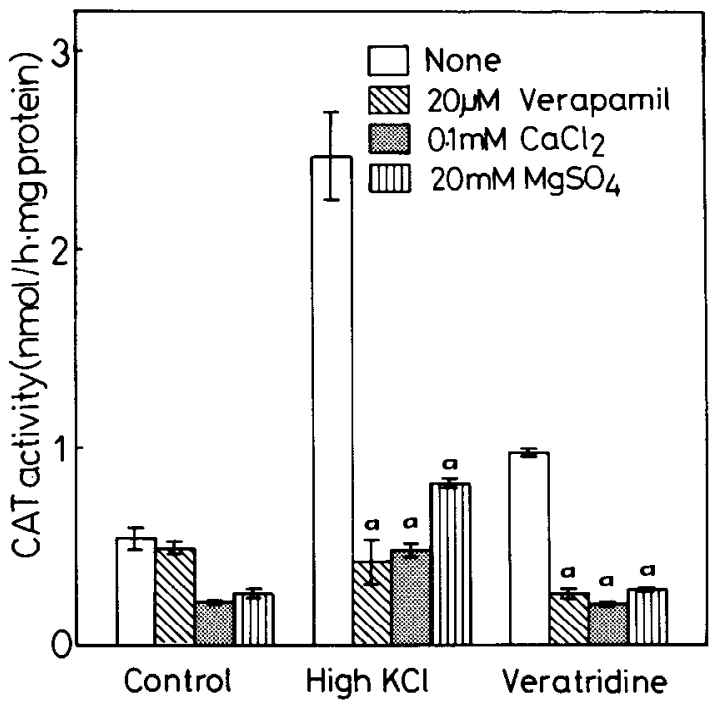

Figure 4. Effect of $\mathrm{Ca}^{2+}$ antagonists on the stimulation of CAT activity by depolarizing agents. Cells were cultured from day 5 to day 11 in normal medium, in a high $\mathrm{KCl}(47 \mathrm{~mm})$ medium, or in the medium containing $3 \mu \mathrm{M}$ veratridine. Verapamil $(20 \mu \mathrm{M})$ or $\mathrm{MgSO}_{4}(20 \mathrm{mM})$ was added to the media when indicated. Low $\mathrm{Ca}^{2+}$ media $(0.1 \mathrm{mM})$ were prepared as described under "Materials and Methods." Columns and bars indicate the mean and SEM of the values of four cultures. $a, p<0.001$ when compared with the values of the cells cultured in either high $\mathrm{KCl}$ or veratridine alone, respectively.

thus indicating that the stimulatory effect of high $\mathrm{KCl}$ was not due to a general enhancement of protein synthesis in the cells. Although high $\mathrm{KCl}$ enhanced the uptake of $\left[{ }^{14} \mathrm{C}\right]$ choline into cells only 1.2 -fold, the synthesis of radiolabeled $\mathrm{ACh}$ from $\left[{ }^{14} \mathrm{C}\right]$ choline was stimulated 4fold, in good agreement with the increase in CAT activity assayed in cell homogenate.

\section{Discussion}

The present study demonstrates that depolarizing agents (i.e., a high concentration of $\mathrm{KCl}$ and veratridine) increase CAT activity in primary cell cultures from the spinal cord of fetal mouse. The increase of CAT activity presumably is due to an increase of enzyme molecules rather than an activation of existing enzymes, because several days of culture were required for an increase of the activity. The depolarizing agents might act on neuronal cells, because the stimulatory effect was still observed after the growth of satellite cells or fibroblasts 
was inhibited by pretreatment with FUdR (data not shown). The result, however, would not exclude the possibility that a subpopulation of FUdR-resistant satellite cells could mediate the effect. High concentrations of $\mathrm{KCl}$ have been found to increase the survival of neuronal cells in several culture systems (Black et al., 1971; Lasher and Zagon, 1972; Philipson and Sandler, 1975; Scott, 1977; Bennett and White, 1979; Chalazonitis and Fischbach, 1980). Nishi and Berg (1981) showed that high $\mathrm{K}^{+}$concentrations stimulated CAT activity 2 -fold but did not increase the survival of neurons cultured from chick ciliary ganglion in the presence of extracts from embryonic eye tissue. In their study, protein synthesis as wcll as the activity of lactatc dehydrogenase, a common cytoplasmic enzyme, was also enhanced by high $\mathrm{KCl}$ to the same extent as CAT activity, indicating a general effect on neuronal growth.

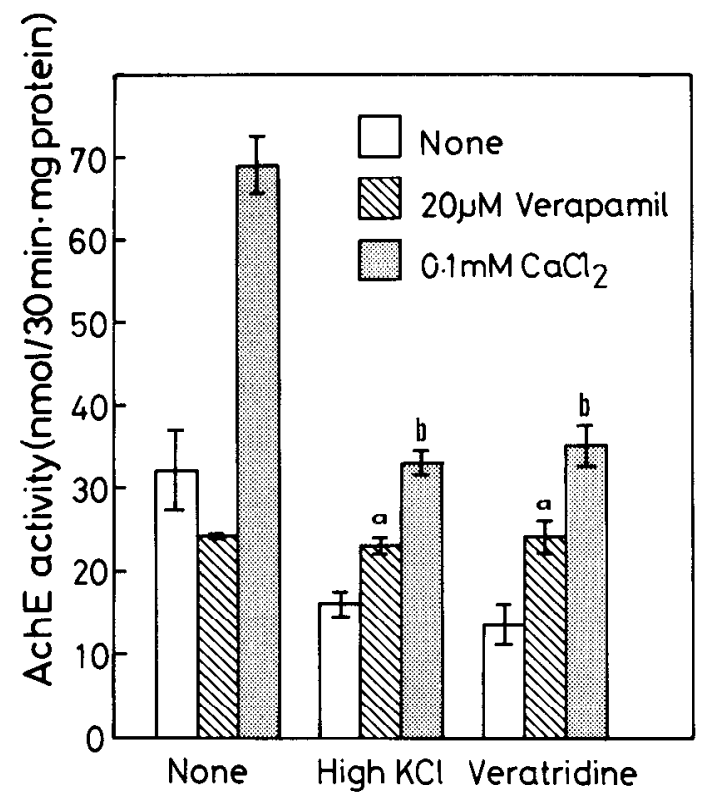

Figure 5. Effect of $\mathrm{Ca}^{2+}$ antagonists on the suppression of AChE activity by depolarizing agents. Cells were cultured from day 5 to day 12 in the same manner as in Figure 4, and $\mathrm{AChE}$ activity was determined. Columns and bars indicate the mean and SEM of the values of four replicate cultures. $a, p<0.02 ; b$, $p<0.001$ compared with the cells cultured in either high $\mathrm{KCl}$ or veratridine alone, respectively.
In our study, the number of neuron-like cells stained for $\mathrm{AChE}$ was not increased by incubation of the cells with a high $\mathrm{KCl}$ medium (high $\mathrm{KCl}$ medium, $54 \pm 20$ cells $/ 0.12 \mathrm{~mm}^{2}$; normal medium, $53 \pm 16$ cells $/ 0.12 \mathrm{~mm}^{2}$ ). Neither the amount of protein nor the synthetic rate of protein from radiolabeled leucine differs between the cells with or without the treatment of high $\mathrm{KCl}$. A high concentration of $\mathrm{KCl}$ markedly stimulated the development of CAT activity in the cells, whereas GAD and AChE activities were suppressed under the same conditions. These observations suggest that the increase of CAT activity by depolarizing agents is due to a specific effect on the new synthesis of CAT molecules. The primary cell cultures employed here, however, are very heterogeneous with respect to cell types. Cholinergic motor neurons represent a small fraction of total cells, and CAT molecules constitute a small portion of total protein. The effect of depolarization on CAT activity could be due to a selective survival of cholinergic neurons or a general stimulation of protein synthesis in CATproducing cells, although the number of $\mathrm{AChE}$-positive neurons and the total protein synthesis were not affected by the treatment. Based on a similar argument, Giller et al. $(1973,1977)$ indicated the specific increase of CAT production in spinal cord cells by co-culture with muscle or muscle-conditioned medium, although other possibilities were discussed to explain their observations.

Our study also indicates that the stimulatory effect of a high $\mathrm{KCl}$ concentration on the development of CAT activity is mediated by the entry of $\mathrm{Ca}^{2+}$. Depolarization has been shown to induce the influx of extracellular $\mathrm{Ca}^{2+}$ into a number of cells in a voltage-dependent manner. Walicke et al. (1977) demonstrated that cholinergic and adrenergic differentiation of neurons from rat superior cervical ganglion was determined by the factor secreted from satellite cells and that the constant depolarization of ganglionic ncurons developed the properties of adrenergic neurons by mediation of $\mathrm{Ca}^{2+}$ entry. In our study, the depolarization of spinal cord neurons enhanced the capability to synthesize $\mathrm{ACh}$, a cholinergic property. The opposite effect of depolarization on neuronal properties between their results and ours could be due to the difference in the cell types employed in the studies. Sympathetic ganglionic neurons are destined to develop as adrenergic neurons, whereas a number of neurons in spinal cord are determined to be cholinergic. Thus the

TABLE II

Effect of a high concentration of $\mathrm{KCl}$ on various metabolisms in spinal cord cells in culture

Spinal cord cells were cultured either in normal medium or in a high $\mathrm{KCl}(47 \mathrm{mM})$ medium from day 5 to day 11 , and the incorporation of $\left[{ }^{3} \mathrm{H}\right]$ leucine, $\left[{ }^{14} \mathrm{C}\right]$ choline, protein content, CAT activity, and $\mathrm{ACh}$ synthesis were measured as described under "Materials and Methods." I'he results are expressed as mean \pm SEM of the values of four replicate cultures.

\begin{tabular}{|c|c|c|c|c|c|c|}
\hline & \multicolumn{2}{|c|}{$\begin{array}{l}{\left[{ }^{3} \mathrm{I}\right] \text { Leucine }} \\
\text { Incorporation } \\
\text { (dpm/well) }\end{array}$} & \multirow[t]{2}{*}{$\begin{array}{l}\text { Total Protein } \\
\text { ( } \mu \mathrm{g} / \text { well })\end{array}$} & \multirow[t]{2}{*}{$\begin{array}{l}{\left[{ }^{14} \mathrm{C}\right] \text { Choline Uptake }} \\
(\mathrm{dpm} / \text { well })\end{array}$} & \multirow[t]{2}{*}{$\begin{array}{l}\text { CAT Activity } \\
(\mathrm{nmol} / \mathrm{hr} \cdot \text { well })\end{array}$} & \multirow[t]{2}{*}{$\begin{array}{l}\text { ACh Synthesis } \\
\text { (pmol/4hr - well) }\end{array}$} \\
\hline & TCA-insoluble & TCA-soluble & & & & \\
\hline Normal medium & $2126 \pm 112$ & $1226 \pm 102$ & $266.3 \pm 22.0$ & $5608 \pm 177$ & $0.135 \pm 0.008$ & $0.75 \pm 0.07$ \\
\hline High $\mathrm{KCl}$ medium & $2087 \pm 12$ & $1663 \pm 80^{a}$ & $263.8 \pm 3.2$ & $6723 \pm 129^{a}$ & $0.410 \pm 0.013^{b}$ & $3.05 \pm 0.04^{b}$ \\
\hline $\begin{array}{l}\text { Ratio (High } \mathrm{KCl} / \text { nor- } \\
\text { mal) }\end{array}$ & 0.97 & 1.36 & 0.99 & 1.20 & 3.04 & 4.07 \\
\hline
\end{tabular}

\footnotetext{
${ }^{a}$ Statistically significant difference in value compared to control cells, $p<0.01$.
}

${ }^{b}$ Statistically significant difference in value compared to control cells, $p<0.001$. 
trans-synaptic stimulation of neurons, possibly via depolarization, during their development would play a crucial role in the maturation of neurons as predetermined cell types. It is, however, undetermined how the depolarization and the entry of $\mathrm{Ca}^{2+}$ into cells influence the developmental fate of neuronal cells in cultures, although $\mathrm{Ca}^{2+}$ has been shown to regulate a number of cellular metabolisms.

We also show that the activity of $\mathrm{AChE}$, the enzyme that metabolizes $\mathrm{ACh}$, in the cultured cells changes in the direction opposite to that of CAT by depolarization and by $\mathrm{Ca}^{2+}$ antagonists. This observation raises the possibility that CAT and AChE activities might be inversely regulated in cholinergic neurons, so as to effectively exert their cholinergic functions.

Presynaptic input would be necessary for the development and maturation of neurons in spinal cord in a similar fashion, as demonstrated for the normal development of postsynaptic adrenergic neurons in superior cervical ganglion in vivo (Black et al., 1971; Black and Geen, 1974; Black, 1978) and for the adrenergic development of sympathetic neurons in cultures (Walicke et al., 1977). The present study proposes one of the mechanisms controlling the activity and function of motor neurons in spinal cord.

\section{References}

Bennett, M. R., and W. White (1979) The survival and development of cholinergic neurons in potassium-enriched media. Brain Res. 173: 549-553.

Black, I. B. (1978) Regulation of autonomic development. Annu. Rev. Neurosci. 1: 182-214.

Black, I. B., and S. C. Geen (1974) Inhibition of the biochemical and morphological maturation of adrenergic neurons by nicotinic receptor blockade. J. Neurochem. 22: 301-306.

Black, I. B., I. A. Hendry, and L. L. Iversen (1971) Transsynaptic regulation of growth and development of adrenergic neurons in a mouse sympathetic ganglion. Brain Res. 34 : 229-240.

Bonting, S. L., and M. Jones (1957) Determination of microgram quantities of deoxyribonucleic acid and protein in tissue grown in vitro. Arch. Biochem. Biophys. 66: 340-353.

Cavallito, C. J., H. S. Yun, T. Kaplan, J. C. Smith, and F. F. Foldes (1970) Choline acetyltransferase inhibitors. Dimensional and substituent effects among styrylpyridine analogs. J. Med. Chem. 12: 221-224.
Chalazonitis, A., and G. D. Fischbach (1980) Elevated potassium induced morphological differentiation of dorsal root ganglionic neurons in dissociated cell culture. Dev. Biol. 78: 173-183.

Fonnum, F. (1975) A rapid radiochemical method for the determination of choline acetyltransferase. J. Neurochem. 24: 407-409.

Giller, E. L., B. K. Schrier, A. Shainberg, H. R. Fisk, and P. G. Nelson (1973) Choline acetyltransferase activity is increased in combined cultures of spinal cord and muscle cells from mice. Science 182: 588-589.

Giller, E. L., J. H. Neale, P. N. Bullock, B. K. Schrier, and P. G. Nelson (1977) Choline acetyltransferase activity of spinal cord cell cultures increased by co-culture with muscle and by muscle-conditioned medium. J. Cell Biol. 74: 16-29.

Hildebrand, J. G., D. L. Barker, E. Herbert, and E. A. Kravitz (1971) Screening for neurotransmitters: A rapid radiochemical procedure. J. Neurobiol. 2: 231-246.

Ishida, I., and T. Deguchi (1983) Regulation of choline acetyltransferase in primary cultures of spinal cord by neurotransmitter L-norepinephrine. Dev. Brain Res. 7: 13-23.

Lasher, J., and R. Zagon (1972) The effect of potassium on neuronal differentiation in cultures of dissociated newborn rat cerebellum. Brain Res. 41: 482-488.

Nishi, R., and D. K. Berg (1981) Effects of high $\mathrm{K}^{+}$concentrations on the growth and development of ciliary ganglion neurons in cell culture. Dev. Biol. 87: 301-307.

Patterson, P. H., and L. Y. Chun (1974) The influence of nonneuronal cells on catecholamine and acetylcholine synthesis and accumulation in cultures of dissociated sympathetic neurons. Proc. Natl. Acad. Sci. U. S. A. 71: 3607-3610.

Philipson, O., and M. Sandler (1975) Potassium depolarization and dibutyryl (cyclic) AMP on explant cultures of chick sympathetic ganglia. Brain Res. 90: 273-281.

Schrier, B. K., and D. L. Shapiro (1974) Effects of fluorodeoxyuridine on growth and choline acetyltransferase activity in fetal rat brain cells in surface culture. J. Neurobiol. 5: 151159 .

Scott, B. S. (1977) The effects of elevated potassium on the time course of neuron survival in cultures of dissociated dorsal root ganglia. J. Cell. Physiol. 91: 305-316.

Walicke, P. A., R. B. Campenot, and P. H. Patterson (1977) Determination of transmitter function by neuronal activity. Proc. Natl. Acad. Sci. U. S. A. 74: 5767-5771.

Wilson, S. H., B. K. Schrier, J. L. Farber, E. J. Thompson, R. N. Rosenberg, A. J. Blume, and M. W. Nierenberg (1972) Markers for gene expression in cultured cells from the nervous system. J. Biol. Chem. 247: 3159-3169. 